\title{
Implementasi Pembelajaran Bahasa Indonesia Materi Menggali Informasi Teks Eksposisi Berbantuan Learning Management System bagi Siswa Kelas X SMA
}

\author{
Ariani Dwi Rusdina ${ }^{1 *}$, Dini Restiyanti Pratiwi ${ }^{1}$ \\ 1. Pendidikan Bahasa dan Sastra Indonesia, FKIP, Universitas Muhammadiyah Surakarta \\ *e-mail: a310170045@student.ums.ac.id
}

(Received: 02-07-2021; Reviewed: 17-07-2021; Accepted: 31-07-2021)

\begin{abstract}
Abstrak
Perubahan proses pembelajaran dari tatap muka menjadi daring dengan memanfaatkan sebuah teknologi yang dikenal dengan istilah Learning Management System. Dengan menggunakan media LMS pada pembelajaran bahasa Indonesia menjadi lebih menarik dan efektif, karena dengan menggunakan media belajar yang berbeda dapat menarik minat siswa untuk semangat dalam belajar. Tujuan dari penelitian ini adalah mendeskripsikan pelaksanaan dan faktor pendukung serta faktor penghambat dalam pembelajaran bahasa Indonesia menggali informasi teks eksposisi berbasis Learning Management System di SMA Negeri 1 Pemalang. Metode yang digunakan dalam penelitian ini adalah penelitian kualitatif. Data dikumpulkan dari dokumentasi perencanaan, pelaksanaan, dan hasil evaluasi pelaksanaan pembelajaran teks eksposisi berbantuan LMS, serta hasil wawancara dengan guru bahasa Indonesia kelas X di SMA Negeri 1 Pemalang. Adapun sumber data dari penelitian ini adalah guru bahasa Indonesia, dokumen mengenai perencanaan, pelaksanaan, dan penilaian. Penelitian ini menggunakan triangulasi sumber, sedangkan jenis analisis data yang digunakan dalam penelitian ini adalah analisis interaktif Miles, Huberman, dan Saldana. Hasil penelitian Indonesia bahwa pelaksanaan pembelajaran bahasa Indonesia pada materi menggali informasi teks eksposisi berbantuan learning management system untuk kelas X di SMA Negeri 1 Pemalang terdapat beberapa faktor pendukung efektifnya pembelajaran LMS, diantaranya yaitu ketersediaan sarana dan prasarana serta penguasaan terhadap LMS yang digunakan. Sedangkan faktor penghambatnya, yaitu antara lain motivasi peserta didik dilihat dari perspektif guru serta pendampingan belajar di rumah.
\end{abstract}

Kata kunci : Learning Management System, Teks Eksposisi.

\begin{abstract}
Changes in the learning process from face to face to online by utilizing a technology known as the Learning Management System. By using LMS media in learning Indonesian, it becomes more interesting and effective, because using different learning media can attract students' interest in learning. The purpose of this study is to describe the implementation and the supporting factors as well as the inhibiting factors in learning Indonesian to explore exposition text information based on the Learning Management System at SMA Negeri 1 Pemalang. The method used in this research is qualitative research. Data were collected from documentation of planning, implementation, and evaluation results of the implementation of LMS-assisted exposition text learning, as well as the results of interviews with Indonesian language teachers in class X at SMA Negeri 1 Pemalang. The data sources of this research are Indonesian language teachers, documents regarding planning, implementation, and assessment. This study uses source triangulation, while the type of data analysis used in this study is the interactive analysis of Miles, Huberman, and Saldana. The results showed that the implementation of Indonesian language learning in the material of digging exposition text information assisted by a learning management system for class X at SMA Negeri 1 Pemalang there were several factors supporting the effectiveness of LMS learning, including the availability of facilities and infrastructure and mastery of the LMS used. While the inhibiting factors, among others, are the motivation of students seen from the perspective of the teacher and mentoring for learning at home.
\end{abstract}

Keywords : Learning Management System, Exposition Text. 


\section{PENDAHULUAN}

Sistem pembelajaran di Indonesia mengalami perubahan sejak Maret 2020 karena adanya penyebaran virus Covid-19 yang semakin meningkat. Perubahan terjadi pada sistem pembelajaran tatap muka menjadi pembelajaran daring. Hal ini sesuai dengan Surat Edaran Menteri Pendidikan dan Kebudayaan Indonesia mengenai pelaksanaan kebijakan pendidikan dalam masa darurat penyebaran Covid-19 Nomor 4 Tahun 2020 poin 2 menjelaskan mengenai proses belajar dari rumah. Berdasarkan pernyataan tersebut setiap jenjang pendidikan harus siap melaksanakan pembelajaran secara daring, baik pada jenjang pendidikan Sekolah Dasar (SD), Sekolah Menengah Pertama (SMP), Sekolah Menengah Atas (SMA), bahkan perguruan tinggi harus merevisi ulang instrumen kegiatan belajar mengajar. Instrumen yang perlu diubah disesuaikan dengan kebijakan surat edaran pemerintah, seperti mengubah metode pembelajaran, sumber belajar, penilaian pembelajaran dan salah satunya adalah media pembelajaran.

Perubahan proses pembelajaran dari tatap muka menjadi daring dengan memanfaatkan teknologi berbasis e-learning. Menurut Rusman (2012) e-learning merupakan segala aktivitas belajar yang menggunakan bantuan teknologi elektronik. Melalui e-learning, pemahaman siswa tentang sebuah materi tidak tergantung pada guru/instruktur tetapi dapat diperoleh dari media elektronik. Dalam penggunaannya $e$-learning membutuhkan sistem yang dapat mengatur kegiatan pembelajaran daring menjadi maksimal, sistem tersebut dikenal dengan istilah Learning Management System. Dengan menggunakan media LMS pada pembelajaran bahasa Indonesia menjadi lebih menarik dan efektif, karena dengan menggunakan media belajar yang berbeda dapat menarik minat siswa untuk semangat dalam belajar.

Media belajar secara daring yang digunakan sangat beragam seperti whatsapp, zoom meeting, google meet maupun Learning Management System yang dapat di akses melalui gadget. Whatsapp, zoom meeting, google meet dan Learning Management System merupakan media yang saat ini cukup efektif digunakan dalam pembelajaran. Penggunaan media elektronik dalam pembelajaran sangat meningkatkan kualitas belajar siswa, pembelajaran menjadi lebih interaktif, lebih fleksibel, lebih produktif, dan menghemat waktu. Namun dari berbagai macam media tersebut tentu masing-masing memiliki kelebihan dan juga kekurangan. Media whatsapp lebih familiar bagi kebanyakan orang, akan tetapi banyak aktivitas pembelajaran yang tertunda. Media zoom meeting merupakan aplikasi video berbasis online. Aplikasi ini dapat digunakan di perangkat seluler, maupun laptop. Pada umumnya aplikasi ini digunakan untuk meeting hingga konferensi video dan audio. Penggunaan zoom meeting dalam pembelajaran daring sangat membantu, karena pada aplikasi ini mendukung penayangan dokumen seperti power point, microsoft word, dan lainlain. Sama halnya dengan zoom meeting, media google meet dalam pembelajaran daring antara guru dan siswa dapat berjalan dengan lancar. Dengan google meet guru maupun siswa dapat menjelaskan dan menampilkan materi yang sedang di sampaikan. Adapun media pembelajaran Learning Management System menurut (Surjono, 2013) adalah sebuah software yang digunakan untuk mengelola sebuah proses pembelajaran.

Berdasarkan hasil observasi awal pembelajaran daring di SMA Negeri 1 Pemalang sudah menggunakan media LMS dengan laman akses http://lms.smansa.top:1233/. Tampilan menu dalam http://lms.smansa.top:1233/ meliputi menu participants, badges, competencies, grades, dashboard, site home, calender, dan private file. Aktivitas pembelajaran berlangsung pada menu grades, dimana guru dapat membuat ruang kelas, daftar presensi, dan kontrak belajar untuk semua mata pelajaran. LMS ini juga bisa diterapkan dalam proses pembelajaran bahasa Indonesia, salah 
satunya diterapkan dalam pembelajaran bahasa Indonesia teks eksposisi kelas X di SMA Negeri 1 Pemalang.

Pembelajaran bahasa Indonesia mengajarkan siswa untuk dapat menggunakan kemampuannya secara fungsional dan autentik dalam berkomunikasi. Menurut Abidin (2012) dapat diartikan sebagai serangkaian aktivitas yang dilakukan siswa untuk mencapai keterampilan berbahasa tertentu, seperti kemampuan berkomunikasi dan kemampuan dalam menggali suatu informasi. Untuk meningkatkan kemampuan dan keterampilan siswa membutuhkan kecukupan media untuk bisa melaksanakan kompetensi-kompetensi itu. Salah satu aktivitas pembelajaran yang harus di tempuh oleh siswa kelas X di SMA Negeri 1 Pemalang adalah KD 3.3 Menganalisis (permasalahan, argumentasi, pengetahuan, dan rekomendasi) teks eksposisi yang didengar dan atau dibaca dan KD 3.4 Menganalisis struktur dan kebahasaan teks eksposisi.. Alasan memilih teks eksposisi karena teks eksposisi mempunyai banyak manfaat bagi siswa salah satunya dapat memperoleh informasi dengan jelas mengenai suatu hal. Melalui teks eksposisi siswa juga bisa mengembangkan atau mengutarakan pemikirannya dan memberikan informasi kepada orang lain. Oleh karena itu, pembelajaran teks eksposisi sangat dibutuhkan siswa untuk ke depannya agar bisa mengutarakan pemikirannya untuk memberikan informasi dan meyakinkan pendengar tentang pentingnya suatu permasalahan. Maka dari itu Kurikulum 2013 dalam pembelajaran teks eksposisi harus baik.

Berdasarkan uraian diatas, pada penelitian ini ditemukan pembaharuan mengenai pelaksanaan pembelajaran bahasa Indonesia pada materi teks eksposisi dengan bantuan Learning Management System. Penelitian ini juga bertujuan untuk mendeskripsikan pelaksanaan pembelajaran bahasa Indonesia pada materi kelas X menggali informasi teks eksposisi berbantuan Learning Management System di SMA Negeri 1 Pemalang serta mendeskripsikan faktor pendukung dan penghambat pelaksanaan pembelajaran bahasa Indonesia pada materi kelas X menggali informasi teks eksposisi berbantuan Learning Management System di SMA Negeri 1 Pemalang. Hasil penelitian ini diharapkan guru dapat memberikan alternatif media pembelajaran dimasa daring menggunakan LMS yang dapat digunakan siswa untuk belajar.

\section{Metode}

Metode yang digunakan dalam penelitian ini adalah penelitian kualitatif. Data kualitatif dikumpulkan melalui teknik wawancara, observasi, dan dokumentasi. Dokumen yang diperoleh berupa dokumen perencanaan pembelajaran bahasa Indonesia pada materi teks eksposisi, dokumen pelaksanaan pembelajaran bahasa Indonesia pada materi teks eksposisi, dan dokumen hasil evaluasi pembelajaran bahasa Indonesia pada materi teks eksposisi. Data hasil wawancara diolah menggunakan model analisis interaktif Miles, Huberman, dan Saldana (Miles, Huberman \& Saldana, 2014) yang meliputi pengumpulan data, kondensasi data, penyajian data, dan penarikan kesimpulan.

Pada penelitian ini mendeskripsikan pelaksanaan pembelajaran bahasa Indonesia menggali informasi teks eksposisi berbantuan LMS dan mendeskripsikan faktor pendukung dan faktor penghambat pelaksanaan pembelajaran berbantuan LMS. Peneliti mengambil lokasi penelitian di SMA Negeri 1 Pemalang yang beralamat di Jalan Gatot Subroto, Bojongbata, Kecamatan Pemalang, Kabupaten Pemalang, Jawa Tengah 52319. Penelitian ini selama 6 bulan terhitung dari bulan September 2020-Februari 2021. Objek dari penelitian ini yaitu aktivitas pembelajaran bahasa Indonesia dengan materi teks eksposisi berbantuan Learning Management System pada 
kelas X di SMA Negeri 1 Pemalang. Sedangkan subjek penelitian ini mengenai pemanfaatan LMS dalam pembelajaran bahasa Indonesia menggali informasi teks eksposisi.

\section{Hasil}

Hasil penelitian menunjukan bahwa pelaksanaan pembelajaran bahasa Indonesia yang dilaksanakan dengan tatap muka sangat berbeda dengan pembelajaran bahasa Indonesia daring berbantu LMS. Pelaksanaan pembelajaran bahasa Indonesia berbantu LMS pada SMA Negeri 1 Pemalang dapat diakses di laman http://lms.smansa.top:1233/. Pelaksanaan pembelajaran bahasa Indonesia pada materi teks eksposisi di LMS mencakup beberapa kegiatan mulai dari kegiatan 1, kegiatan 3, kegiatan 4, kegiatan 5, kegiatan 6, dan kegiatan 7 . Selanjutnya uraian aktivitas kegiatan 1 sampai dengan kegiatan 7 diuraikan dengan tabel berikut ini.

Tabel 1 Aktivitas kegiatan pembelajaran teks eksposisi melalui LMS

\begin{tabular}{|c|c|}
\hline Kegiatan ke- & Konten \\
\hline Kegiatan 1 & Video tayangan materi teks eksposisi \\
\hline Kegiatan 3 & Lembar kerja siswa 1 \\
\hline Kegiatan 4 & Diskusi materi teks eksposisi \\
\hline Kegiatan 5 & Lembar kerja siswa 2 \\
\hline Kegiatan 6 & Tautan google meet \\
\hline Kegiatan 7 & Lembar kerja siswa 3 \\
\hline
\end{tabular}

Dalam kegiatan 1 terjadi aktivitas peserta didik mengamati video tayangan materi teks eksposisi secara langsung melalui LMS atau dapat diakses melalui youtube. Di dalam kegiatan ini guru telah menyediakan video referensi pembelajaran materi teks eksposisi yang di unggah melalui LMS tepatnya pada forum video referensi teks eksposisi. Kegiatan 3 guru membuat lembar kerja siswa. Lembar kerja siswa sendiri dibagi menjadi 3 bagian, yang pertama lembar kerja siswa 1, lembar kerja siswa 2, dan lembar kerja siswa 3. Pada kegiatan 3 ini guru membuat forum lembar kerja siswa 1, dalam forum ini terjadi aktivitas peserta didik mengerjakan latihan soal yang diberikan guru sebagai tugas harian. Di dalam kegiatan ini guru telah membuat dan merancang soal berupa pertanyaan dari materi yang telah di pelajari, pada lembar kerja 1 materi yang di berikan berkaitan dengan KD 3.3 yakni mengidentifikasi (permasalahan, argumentasi, pengetahuan, dan rekomendasi) teks eksposisi yang didengar dan atau dibaca.

Kegiatan 4 ada forum diskusi, dalam kegiatan ini terjadi aktivitas tanya jawab antara guru dan peserta didik. Forum diskusi dibuat untuk mempermudah guru dengan peserta didik dalam melakukan sesi tanya jawab seputar materi teks eksposisi. Di dalam kegiatan forum diskusi guru memberikan kesempatan kepada peserta didik untuk bertanya mengenai materi yang dianggap sulit. Dari sekian banyak peserta didik hanya sebagian anak saja yang aktif bertanya. Ketika pertanyaan sudah diberikan oleh peserta didik, maka guru memberikan kesempatan kepada peserta didik yang lain untuk menjawabnya, apabila tidak ada yang bisa menjawab maka gurulah yang akan menjawab pertanyaan tersebut. Akan tetapi, tampilan forum diskusi yang disediakan pada LMS ini sama seperti tampilan komentar di sosial media. Artinya, ketika guru ingin menjawab pertanyaan dari peserta didik guru mengalami kendala, sebab guru tidak bisa menjawab langsung pertanyaan tersebut.

Pada kegiatan 5 guru membuat forum lembar kerja siswa 2 dengan memberikan tugas harian mengenai materi 3.4 yakni menganalisis struktur dan kebahasaan teks eksposisi. Dengan 
forum yang disediakan di LMS peserta didik dapat dengan mudah dalam pengumpulan tugas. Tugas yang diberikan berupa kuis, seperti pilihan ganda, benar-salah, jawaban singkat, dan drag dan drop gambar dan teks. Kegiatan 6 guru membuat forum dengan menautkan tautan google meet pada materi teks eksposisi. Pada kegiatan ini guru menautkan tautan yang mengarahkan langsung ke google meet. Forum ini digunakan untuk melakukan konfrimasi dan refleksi dari kegiatan 1 sampai kegiatan 5 yang telah dilakukan peserta didik secara mandiri. Pada pertemuan google meet guru bertanya kepada peserta didik mengenai hasil belajarnya saat mengikuti pembelajaran. Guru juga memberi pertanyaan dan membuka pertanyaan kepada peserta didik mengenai materi teks eksposisi.

Selanjutnya kegiatan 7 sebagai kegiatan penutup di dalamnya terdapat lembar kerja siswa 3 yang berisi ulangan harian. Lembar kerja 3 ini berbeda dengan lembar kerja 1 dan lembar kerja 2 yang berisi tugas harian. Melalui lembar kerja 3 ini guru menyajikan soal ulangan harian yang memuat KD pengetahuan 3.3 yakni mengidentifikasi (permasalahan, argumentasi, pengetahuan, dan rekomendasi) teks eksposisi yang didengar dan atau dibaca dan KD 3.4 yakni menganalisis struktur dan kebahasaan teks eksposisi. Bentuk ulangan harian ini berupa kuis seperti soal pilihan ganda, benar-salah, jawaban singkat, dan drag dan drop gambar dan teks.

Dalam pelaksanaan pembelajaran teks eksposisi berbantu LMS ditemukan beberapa faktor pendukung dan faktor penghambat pelaksanaannya. Faktor pendukung pelaksanaan pembelajaran berbantu LMS sebagai berikut.

1. Ketersediaan sarana dan prasarana serta

Dalam mengakses LMS dibutuhkan perangkat penunjang, seperti komputer, laptop, dan gatget untuk bisa menggunakan LMS. Di SMA Negeri 1 Pemalang sekolah menyediakan komputer dan gatget gratis kepada peserta didik yang kurang mampu. Program peminjaman gatget secara gratis ini sekolah bekerja sama dengan para alumi dari SMA Negeri 1 Pemalang. Penggunaan LMS juga memerlukan koneksi internet yang stabil dan bagus. Jika tidak, proses pembelajaran melalui LMS akan tertunda. Di SMA Negeri 1 Pemalang sendiri memberikan fasilitas berupa kuota gratis kepada guru dan peserta didiknya. Selain itu, pemerintah juga memberikan bantuan kuota gratis untuk guru dan semua peserta didik. Dengan adanya bantuan kuota gratis ini pembelajaran melalui LMS dapat berjalan dengan baik dan peserta didik dapat mengikuti setiap pertemuannya.

\section{Penguasaan terhadap LMS yang digunakan}

Pembelajaran dengan memanfaatkan LMS menggunakan beberapa teknologi informasi berupa gambar, suara, animasi, video, dan teks. Dalam hal ini guru harus memiliki keterampilan dalam mengoperasikan teknologi tersebut dengan baik. Di masa pembelajaran daring ini LMS sangat dibutuhkan sebagai media pembelajaran yang mudah digunakan. LMS mempermudah guru untuk mengumpulkan dan menganalisis data hasil belajar peserta didik dengan waktu yang lebih singkat. Sebelum media LMS diterapkan untuk pembelajaran daring, guru diwajibkan mengikuti pelatihan mengenai pelaksanaan dan penggunaan LMS yang diadakan sekolah. Setiap minggu diadakan pelatihan guna memperkuat keterampilan guru dalam menguasai LMS.

Selain faktor pendukung di atas, faktor penghambat juga berpengaruh besar terhadap pelaksanaan pembelajaran teks eksposisi sebagai berikut.

1. Motivasi peserta didik dilihat dari perspektif guru

Kemalasan belajar yang di miliki oleh peserta didik menjadi faktor penghambat guru ketika mengajar. Sebagian anak kurang menyukai pembelajaran daring hal ini di sebabkan karena rasa bosan dan rasa malas yang timbul dari dalam diri anak dapat disebabkan karena kurang atau tidak 
adanya motivasi diri. Motivasi ini kemungkinan belum tumbuh dikarenakan anak belum mengetahui manfaat dari belajar atau belum ada sesuatu yang ingin dicapainya. Selain itu kelelahan dalam beraktivitas dapat berakibat menurunnya kekuatan fisik dan melemahnya kondisi psikis. Proses pembelajaran akan berhasil manakala peserta didik mempunyai motivasi dalam belajar. Oleh sebab itu, guru perlu menumbuhkan motivasi belajar pada peserta didik. Untuk memperoleh hasil belajar yang optimal, guru dituntut kreatif membangkitkan motivasi belajar anak didiknya sehingga terbentuk perilaku belajar yang efektif. Guru juga harus bisa memberikan motivasi semangat belajar kepada anak didiknya. Hal yang dapat guru lakukan adalah meningkatkan kualitas pembelajarannya dengan menggunakan fasilitas pembelajaran dari LMS. Motivasi yang diberikan dapat berupa tayangan video seseorang yang telah mencapai kesuksesan, selain itu guru juga dapat bercerita bagaimana gambaran hidup di masa depan.

\section{Pendampingan belajar di rumah.}

Kesibukan pekerjaan yang dilakukan oleh orang tua berdampak buruk kepada anaknya. Anak menjadi terabaikan dan kurang perhatian dari orang tuanya. Kurangnya motivasi dan semangat dari orang tua juga berpengaruh besar terhadap prestasi anaknya di sekolah. Perlunya pendampingan orang tua kepada anaknya dapat meningkatkan kedisiplinan anak dalam belajar, meningkatkan motivasi anak untuk belajar. Dengan adanya bimbingan dari orang tua, mereka dapat mengawasi dan mengetahui segala kekurangan dan kesulitan belajar anaknya. Pengawasan dan bimbingan orang tua di rumah sangat diperlukan karena orang tua berperan besar dalam mengajar, mendidik, memberikan bimbingan, serta menyediakan sarana belajar.

\section{Pembahasan}

Hasil penelitian mengungkapkan bahwa pembelajaran bahasa Indonesia pada materi teks eksposisi berbantu LMS peserta didik cenderung lebih menyukai pembelajaran secara tatap muka dari pada pembelajaran daring melalui LMS. Dari berbagai sekolah yang ada di lingkungan Kabupaten Pemalang, SMA Negeri 1 Pemalang merupakan satu-satunya sekolah yang memanfaatkan LMS sebagai media pembelajaran. Dengan demikian penerapan LMS di dalam pembelajaran teks eksposisi di sekolah belum dapat dibandingkan dengan sekolah lain di kabupaten yang sama.

Penelitian terkait pelaksanaan LMS dalam pembelajaran di sekolah sebelumnya sudah dilakukan oleh Putra et al. (2019) yang berkaitan dengan media LMS di sekolah ini memiliki persamaan dengan penelitian ini yaitu sama-sama LMS digunakan sebagai media pembelajaran di sekolah. Perbedaan antara keduanya terletak pada metode penelitian. Pada penelitian ini hanya menggunakan metode penelitian kualitatif, sedangkan pada penelitian yang dilakukan oleh Putra et al. (2019) menggunakan metode penelitian evaluatif dengan tipe model evaluasi CIPP (context, input, process, product). Selain itu penelitian ini hanya mendeskripsikan pelaksanaan pembelajaran bahasa Indonesia pada materi teks eksposisi kelas X di SMA Negeri 1 Pemlang, sedangkan penelitian Putra et al. (2019) menguji pelaksanaan LMS sebagai media untuk ujian online siswa kelas X di SMKN 1 Jakarta pada Program Studi Bidang DPIB (Desain Permodelan dan Infromasi Bangunan).

Persamaan penelitian Juwita et. al (2012) dengan penelitian ini yaitu sama-sama menggunakan model pembelajaran LMS, yang menjadi pembeda adalah objek kajian yang diteliti. Jika penelitian ini objek kajiannya siswa kelas X SMA Negeri 1 Pemalang, sedangkan penelitian Juwita et. al (2012) objeknya adalah semua siswa kelas VII, VIII, dan IX di SMP Negeri 21 
Semarang. Dalam penelitian Permana (2013) menjelaskan bahwa penelitian ini sama-sama meneliti LMS. Hal yang membedakan penelitian ini dengan sebelumnya adalah sumber data yang diteliti. Jika penelitian ini sumber datanya adalah siswa kelas $\mathrm{X}$ saat proses pembelajaran menggali informasi teks eksposisi, sedangkan Permana (2013) meneliti keefektivan LMS dalam meningkatkan kemampuan menulis mahasiswa jurusan bahasa Jerman.

Penelitian lain mengenai LMS yang dilakukan oleh Wibowo et. al (2014) yaitu sama-sama menggunakan LMS. Hal yang membedakan penelitian ini dengan sebelumnya adalah sumber data yang diteliti. Jika penelitian ini sumber datanya adalah siswa SMA kelas $X$ saat proses pembelajaran menggali informasi teks eksposisi, sedangkan penelitian Oktaviani (2018) dengan penelitian ini adalah sama-sama mengenai media LMS, yang membedakan penelitian Oktaviani (2018) dengan penelitian ini adalah objek yang dituju, jika dalam penelitian ini objeknya adalah siswa kelas X di SMA Negeri 1 Pemalang sedangkan penelitian Oktaviani (2018) objeknya adalah mahasiswa.

Penelitian selanjutnya yang dilakukan oleh Fitriani (2020) dengan penelitian ini peneliti sama-sama meneliti Learning Management System. Hal yang membedakan penelitian ini dengan penelitian Fitriani (2020) adalah Learning Management System yang digunakan tidak hanya satu, seperti Google Classroom, Edmodo, Moodle, serta SEVIMA Edlink.

\section{Kesimpulan}

Melalui penelitian yang telah dilaksanakan oleh peneliti ini, dapat diketahui bahwa dalam pelaksanaan pembelajaran bahasa Indonesia pada materi menggali informasi teks eksposisi berbantuan learning management system untuk kelas X di SMAN 1 Pemalang terdapat beberapa faktor pendukung efektifnya pembelajaran LMS. Faktor-faktor tersebut diantaranya yaitu ketersediaan sarana dan prasarana serta penguasaan terhadap LMS yang digunakan. Selain faktor pendukung di atas, faktor penghambat juga berpengaruh besar terhadap pembelajaran diantaranya yaitu motivasi peserta didik dilihat dari perspektif guru serta pendampingan belajar di rumah. Setelah penelitian ini dilaksanakan, ditemukan beberapa keterbatasan yang ditemukan, antara lain: Penelitian ini tidak membahas hasil belajar peserta didik saat menggunakan LMS dan tidak mengkaji berapa persentase keefektifan penggunaan media LMS, melainkan hanya mendeskripsikan pelaksanaan pembelajaran LMS pada mata pelajaran bahasa Indonesia kelas X materi teks eksposisi di SMA Negeri 1 Pemalang dan hanya membahas penerapan, pelaksanaan, dan hasil evaluasi pembelajarannya saja. Penelitian ini diharapkan mampu mencapai suatu tujuan secara optimal dan dapat memberi manfaat, menambah pengetahuan dalam pemanfaatan media teknologi dan menambah wawasan belajar bagi penulis dan pembaca.

\section{Referensi}

Abidin, Yunus. 2012. Pembelajaran Bahasa Indonesia Berbasis Pendidikan Karakter. Bandung: PT. Refiak Aditama

Bambang, Riyanto. 2012. Dasar-Dasar Pembelajaran Edisi 4. Yogyakarta: BPFE.

Efrita, Karlina, dkk. 2016. "Pengembangan E-learning Menggunakan LMS (Learning Managemet System) untuk Mahasiswa Pendidikan Fisika". Prosiding Snips, 21-22. 
Ellis, K. Ryann. 2009. A Field Guide to Learning Management System. American

Fitriani, Yuni. 2020. “Analisa Pemanfaatan Learning Management System (LMS) Sebagai Media Pembelajaran Online Selama Pandemi Covid-19". Journal of Information System Informatics and Computing, 4(2):2-5.

Juwita, Ratna, dkk. 2012. "Pengembangan Model Pembelajaran Konstruktivistik Menggunakan LMS Moodle di SMP Negeri 21 Semarang". Innovative Journal of Curriculum and Educational Technology, 1(1):31-35.

Lailatussaadah. 2020. "Faktor-Faktor Penunjang dan Penghambat Pelaksanaan Pembelajaran Daring (Online) PPG dalam Jabatan (Daljab) Pada Guru Perempuan di Aceh”. International Journal of Child and Gender Studies, 6(2):45-45.

Lantip Diat Prasojo \& Riyanto. 2011. Teknologi informasi pendidikan. Yogyakarta: Gava Media.

Mahsun. 2014. Teks dalam Pemebelajran Bahasa Indonesia Kurikulum 2013. Jakarta: PT Raja Grafindo Persada.

Milles, Huberman, dan Saldana. 2014. Qualitative Data Analysis A Methods Sourcebook (Edition 3). Sage Publications. Inc.

Moleong. 2014. Metode Penelitian Kualitatif Edisi Revisi. Jakarta: Remaja Rosda Karya.

Oktaviani, Dian, dkk. 2018. "Persepsi Mahasiswa Terhadap Kepraktisan Learning Management System Moodle Berbasis Teori Behaviorisme”. Jurnal Pendidikan Matematika, 6(3):307-309.

Permana, Pepen. 2013. "Efektivitas Penerapan Learning Management System (LMS) dalam Meningkatkan Kemampuan Menulis Mahasiswa Bahasa Jerman”. Allemania, 2(2):136-137.

Priyatni. 2014. Desain Pembelajaran Bahasa Indonesia dalam Kurikulum 2013. Jakarta: Bumi Aksara.

Putra, Rian L, dkk. 2019. "Evaluasi Program Pelaksanaan Ujian Online dengan Menggunakan Learning Management System Moodle Berbasis Android di SMK Negeri 1 Jakarta". Jurnal Pendidikan Teknik Sipil, 8(1):48-49.

Raharja, Setya, dkk. 2011. "Model Pembelajaran Berbasis Learning Management System dengan Pengembangan Software Moodle di SMA Negeri Kota Yogyakarta". Jurnal Kependidikan, 41(1):55-70.

Rusman. 2012. Model-Model Pembelajaran. Depok: PT Rajagrafindo Persada.

Saiful. 2012. “Pembinaan Profesionalitas Guru Pendidikan Agama Islam”. Ta’dib, 11(1):59.

Sugiyono. 2016. Metode Penelitian Pendidikan: Pendekatan Kuantitatif, Kualitatif, dan RnD. Bandung: Alfabeta.

Surjono, H.D. 2013. Membangun Course E-learning Berbasis Moodle. Yogyakarta: UNY Press.

Wibowo, Agung, dkk. 2014. "Pengembangan LMS (Learning Management System) Berbasis Web untuk Mengukur Pemahaman Konsep dan Karakter Siswa”. Scientific Journal of Informatics, 1(2): 127. 